\title{
Retraction Note: Gene expression profiles analysis identifies key genes for acute lung injury in patients with sepsis
}

Zhiqiang Guo ${ }^{\dagger}$, Chuncheng Zhao ${ }^{\dagger}$ and Zheng Wang ${ }^{*}$

\section{Retraction}

The Publisher and Editor regretfully retract this article [1] because the peer-review process was inappropriately influenced and compromised. As a result, the scientific integrity of the article cannot be guaranteed. A systematic and detailed investigation suggests that a third party was involved in supplying fabricated details of potential peer reviewers for a large number of manuscripts submitted to different journals. In accordance with recommendations from COPE we have retracted all affected published articles, including this one. It was not possible to determine whether the authors of this particular article were aware of any third party attempts to manipulate peer review of their manuscript.

Received: 3 March 2015 Accepted: 3 March 2015

Published online: 13 May 2015

\section{Reference}

1. Guo Z, Zhao C, Wang Z. Gene expression profiles analysis identifies key genes for acute lung injury in patients with sepsis. Diagn Pathol. 2013;8:176.

* Correspondence: zhengwangww@163.com

${ }^{\dagger}$ Equal contributors

Department of Thoracic surgery, Putuo Hospital, Shanghai University of

Traditional Chinese Medicine, No. 164 Lan Xi Road, Putuo District, 200062

Shanghai, China

Submit your next manuscript to BioMed Central and take full advantage of:

- Convenient online submission

- Thorough peer review

- No space constraints or color figure charges

- Immediate publication on acceptance

- Inclusion in PubMed, CAS, Scopus and Google Scholar

- Research which is freely available for redistribution Submit your manuscript at
www.biomedcentral.com/submit 